\title{
Perceptions on the strategic value of corporate social responsibility - some insights from global rankings
}

\author{
Ogrean Claudia \\ "Lucian Blaga" University of Sibiu \\ Romania \\ claudia.ogrean@ulbsibiu.ro
}

\begin{abstract}
Due to the tremendous challenges of nowadays, most of the global companies behave (or, at least, declare to behave) as responsible global citizens. But, the real battle on the field of CSR seems now to be played in terms of perceived legitimacy of companies - through the lens of their stakeholders. As CSR increasingly become a barometer reflecting a company's relationships with its stakeholders, the paper aims to identify, based on a comparative analysis: the companies that have the best perceived images (in terms of admiration, reputation and brand value) as reflection of their approaches towards CSR; the strategic value of the global winners' CSR involvement as perceived through external lens - consumers, executives, directors and analysts. The results will enable a better understanding of the real role CSR plays within the global companies, while the conclusions are making suggestions on the better capitalization of the strategic value of CSR.
\end{abstract}

Received: May, 2014 1st Revision: September, 2014

Accepted: October, 2014

Keywords: Corporate Social Responsibility; Stakeholders; World's Most Admired Companies for Social Responsibility; Global CSR Reputation Winners; Best Global Green Brands.

JEL classification: F01; L14; M14.

\section{INTRODUCTION}

Corporate Social Responsibility (CSR) is not a new concept and/or practice; however, it still causes a lot of confusion and misinterpreting, while raising a whole plethora of questions and controversies regarding its drivers, its means, and its ends. Beyond the academic debates - that illustrate the vivid dynamics of an evolving and transformative concept and practice, but also justify, to a certain degree, the lack of coherence and/ or common understanding - this is particularly the case for companies, and especially for the global ones, that are largely engaged in different CSR activities and practices (as genuine or just fashionable behaviors; implicitly or explicitly assumed; in the benefit of shareholders or having all the stakeholders in mind; aiming for strategic, long-term value creation and capitalization or just for short-term "cleaning" or benefits), but which "are largely in dark when it comes to understanding how their stakeholders think and feel" about their programs (Bhattacharya, Sen \& Korschun, 2011, p. i). 
It might be difficult for a company to evaluate by itself the (strategic) impact of its CSR practices; as Becerra (2009) outlines, in order for such a strategic analysis to really achieve its goal, "we will have to look outside the firm and how its strategy around a collection of specific resources deals with customers, competitors, and external resources" (Becerra, 2009, p. 251). However, this kind of unilateral approach would not place the company among its peers within an industry and/or country - which is essential in terms of strategic positioning and competitiveness. The "good news" here is the emergence of global rankings - annually released by prestigious bodies (research institutes and media groups), which become referential for both companies - aiming to be on the "winners lists" on one hand, and trying to capitalize the best on this presence, on the other hand - and their stakeholders.

Therefore, the paper comparatively analyzes three pairs of such global winners: (1). The World's Most Admired Companies and the World's Most Admired Companies for Social Responsibility - according to Fortune \& Hay Group; (2). The World's Most Reputable Companies and the Global CSR reputation Winners - according to the Reputation Institute \& Forbes; and (3). The Best Global Brands and the Best Global Green Brands - according to Interbrand. There are also other rankings - such as the World's Most Ethical Companies (http://ethisphere.com/); the 100 Best Corporate Citizens (http://www.forbes.com/) - and metrics - Dow Jones Sustainability Indices (http://www.sustainability-indices.com/); Corporate Responsibility Indices (http://thomsonreuters.com/corporate-responsibility-indices/) - but the reason for choosing the aforementioned three pairs relies on the possibility of making comparisons on similar bases between the companies that rank better on Top 10 general/narrow and the companies that are in Top 10 on a CSR strictly related dimension.

The analysis aims to identify: (a). the companies that have the best perceived images - as reflection of their CSR involvement - based on the similar assessment grounds of each ranking; (b). the similarities and the differences between the three pairs of rankings - considering their different methodological approaches; (c). the strategic value of the global winners' CSR involvement as perceived through external lens - consumers, executives, directors and analysts. As CSR increasingly become a barometer reflecting a company's relationships with its stakeholders, companies must be more aware of the impacts their CSR related behaviors have - if not in order to organically fit within their internal and external environment, at least in order to get the best value for their CSR invested resources.

Following a concise literature review aiming to set the theoretical framework and the contextual background that define the study, the paper will then emphasize on the perceived legitimacy of companies, in order to get some insights on the strategic value of their CSR. Three globally recognized rankings will serve as sample for the comparative analysis of the best global companies in the field of CSR - based on admiration, reputation and brand value. Some reflections on how the business case for CSR is served by the "global winners" will lead to the final conclusions of the study.

\section{LITERATURE REVIEW}

During the last half of century, the evolution of CSR as both concept and practice was in the focus of the academic literature (Carroll, 1999; Salzmann, Ionescu-Somers \& Steger, 2005; Kolk \& Van Tulder, 2010) in a variety of fields (from marketing to international business). It even generated new lines of research (in strategic management, for instance), or an entirely new, dedicated field of research. Although the field of CSR research continues to be rather scattered, a lot of evolutionary, as well as revolutionary steps have been taken towards an integrated view and a comprehensive understanding of CSR (Kotler \& Lee, 2005; Blowfield \& Murray, 2011). 
But nowadays, the challenges of "smart globalization" (Gupta \& Westney, 2003) or those of sustainable development (Hopwood, Mellor \& O’Brien 2005) rise new opportunities and threats in front of the global players (Bansal, 2002; Crane, Matten \& Spence, 2008; Hahn, 2011), asking for the reconsideration of the old CSR business models. Therefore, strategic changes need to be considered by companies when developing and implementing their CSR related decisions and behaviors, in order to improve their approaches towards stakeholders (Freeman, 2010). The CSR solution for the "soulless corporation" that Friedman and Miles (2006) have identified - based on a stakeholder approach, together with the new stakeholder theories (Friedman \& Miles, 2002) and models (Fassin, 2009) offer significant new insights on the subject, while opening new perspectives for both academia and business as regards the strategic relationships between businesses and society.

Under these circumstances, strategic CSR and the strategic value of CSR are two of the concepts that need a closer look.

The firm's perspective on the strategic CSR argues that strategic CSR is "any responsible activity that allows a firm to achieve a sustainable competitive advantage, regardless of motive" (McWilliams, \& Siegel, 2011); it emphasizes on the idea that strategic CSR “can be defined as voluntary actions that enhance a firm's competitiveness and reputation. The end result of such activities should be an improvement in financial and economic performance" (Orlitzky, Siegel \& Waldman, 2011).

Although this kind of "minimalist involvement" approach outlines a company's benefits from CSR, it disregards the motives, on one hand, and rather treats the effects of CSR on anyone but the company itself as by-products, on the other hand. Clearly, CSR activities are not in the business strategy's core, but the business case for CSR (Carroll \& Shabana, 2010) is entirely served. At the end, even the advocates of the shareholder's interests would be satisfied and the managers will be able to properly exercise their contracts as agents (not to mention the benefits in terms of wider good).

On the other hand, embracing a stakeholder view, Werther and Chandler (2011) advocate the case for strategic CSR, arguing that "there are four components that are essential to defining strategic CSR: first, that firms incorporate a CSR perspective within their strategic planning process; second, that any actions they take are directly related to core operations; third, that they incorporate a stakeholder perspective; and fourth, that they shift from a short-term perspective to managing the firm's resources and relations with key stakeholders over the medium to long term" (Werther and Chandler, 2011, p. 40).

This second approach of the strategic CSR is, obviously, more integrated and comprehensive, but less connected to the company's classical "bottom line", and closer to the "triple bottom line" perspective (Elkington, 1999) - which could be a serious drawback. But it can be visualized and targeted: as companies will engage themselves into strategic CSR by assuming the first view on it, and as they will see its (strategic) benefits in terms of competitiveness and reputation, this could be the next step to take, the new approach to embrace.

The strategic value of CSR emphasizes once more on the idea of stakeholder symbiosis and synergy. Starting with Porter \& Kramer's (2006) fundamental article on "The link between competitive advantage and corporate social responsibility", a quite numerous number of scientific references started to occur, most of them treating the value of CSR through the lens of a single stakeholder category: Servaes \& Tamayo (2013) analyse "The impact of corporate social responsibility on firm value: The role of customer awareness"; Jo \& Harjoto (2011) study "Corporate governance and firm value: The impact of corporate social responsibility"; Gholami (2011) develops a "Value Creation Model through Corporate Social Responsibility (CSR)"; Peloza \& Shang (2011) propose "a systematic review" on "How can corporate social responsibility activities create value for stakeholders?"; Morand \& Rayman-Bacchus (2006) advocate for "Think global, act local: Corporate Social Responsibility Management in Multinational Companies". 


\section{THE BEST GLOBAL COMPANIES IN THE FIELD OF CSR}

CSR commitment and CSR reporting are no longer sources of competitive advantages for the global players (solely based on the grounds of no matter what the actual approach really is). Due to the challenges of nowadays (and especially because of the constraints and pressures coming from very different groups of stakeholders: consumers, NGOs, regulation bodies and so on), most of them behave (or, at least, declare to behave - through their CSR strategies and management structures, on one hand, and through their CSR reporting, on the other hand) as responsible global citizens.

But, as beauty is in the eye of the beholder, it may be said that the strategic value of CSR is rather a question of perception. However, this could be a tricky issue: because there are no universal standards or a unique framework governing companies' behaviors in this field, their approaches toward CSR are quite different, especially if taking into account their cultural backgrounds - see, for instance, the "explicit CSR" that dominates US companies, versus the "implicit CSR" practiced by the European companies (Matten, \& Moon, 2008), on one hand, or the national regulatory bodies "enforcing" CSR in some countries (Lin, 2010; Mukherjee, 2013; Rahim, 2013), on the other hand.

Thereby, the real battle on the field of CSR seems to be played now in terms of perceived legitimacy of companies - through the lens of their stakeholders. Considering this, there are at least three different global rankings that can be considered as benchmarks in the field, and which emphasize on: Social Responsibility (Fortune \& Hay Group: World's Most Admired Companies); Global CSR Reputation Winners (Reputation Institute \& Forbes: The World's Most Reputable Companies); and Best Global Green Brands (Interbrand: Best Global Brands). Some insights on the top 10 "global winners" for each one of the aforementioned rankings are made bellow.

\subsection{Fortune \& Hay Group: World's Most Admired Companies}

Since 1997, Fortune and Hay Group rank the World's Most Admired Companies - starting from a reference base of about 1400 companies (top 1000 US companies by revenue plus Fortune 500 companies from all over the world having revenues of $\$ 10$ billion on more), and arriving to a total of 687 companies from 30 countries survey. The entire methodology of ranking - based on the opinions of 3800 selected executives, directors and analysts - is presented by Fortune on its dedicated website (http://money.cnn.com/ magazines/fortune/most-admired/2013/faq/index.html?iid=wma_fl_method).

The 2013 ranking is based on nine key attributes of reputation: (1). innovation; (2). people management; (3). use of corporate assets; (4). social responsibility; (5). quality of management; (6). financial soundness; (7). long-term investment; (8). quality of products/services; (9). global competitiveness (Fortune, 2013). Table 1 and Figure 1 comparatively illustrate Top 10 rankings for Social Responsibility and World's Most Admired Companies. 
2013 World's Most Admired Companies - Social Responsibility

\begin{tabular}{|c|c|c|c|c|c|c|}
\hline \multirow[b]{2}{*}{ Rank } & \multirow[b]{2}{*}{ Company } & \multicolumn{5}{|c|}{ World's Most Admired Companies (Top 50) } \\
\hline & & Rank & $\begin{array}{c}\text { Overall } \\
\text { score }\end{array}$ & Rank & Company & $\begin{array}{c}\text { Overall } \\
\text { score }\end{array}$ \\
\hline 1. & Marriott International & 39 & 6.83 & 1. & Apple & 8.24 \\
\hline 2. & Starbucks & 5 & 7.85 & 2. & Google & 8.01 \\
\hline 3. & Whole Foods Market & 20 & 7.45 & 3. & Amazon & 7.28 \\
\hline 4. & Royal Dutch Shell & $\mathrm{N} / \mathrm{A}$ & 7.49 & 4. & Coca Cola & 7.32 \\
\hline 5. & $\mathrm{CH} 2 \mathrm{M}$ Hill & $\mathrm{N} / \mathrm{A}$ & 6.57 & 5. & Starbucks & 7.94 \\
\hline 6. & Nike & 13 & 7.37 & 6. & IBM & 7.37 \\
\hline 7. & Nestle & 31 & 7.98 & 7. & Southwest Airlines & 5.52 \\
\hline 8. & The Walt Disney Company & 7 & 8.41 & 8. & Berkshire Hathaway & 7.18 \\
\hline 9. & Statoil & N/A & 7.09 & 9. & The Walt Disney Company & 7.84 \\
\hline 10. & Wyndham Worldwide & N/A & 7.21 & 10. & Fed Ex & 7.00 \\
\hline
\end{tabular}

Source: (Fortune \& Hay Group, 2013, http://money.cnn.com/)

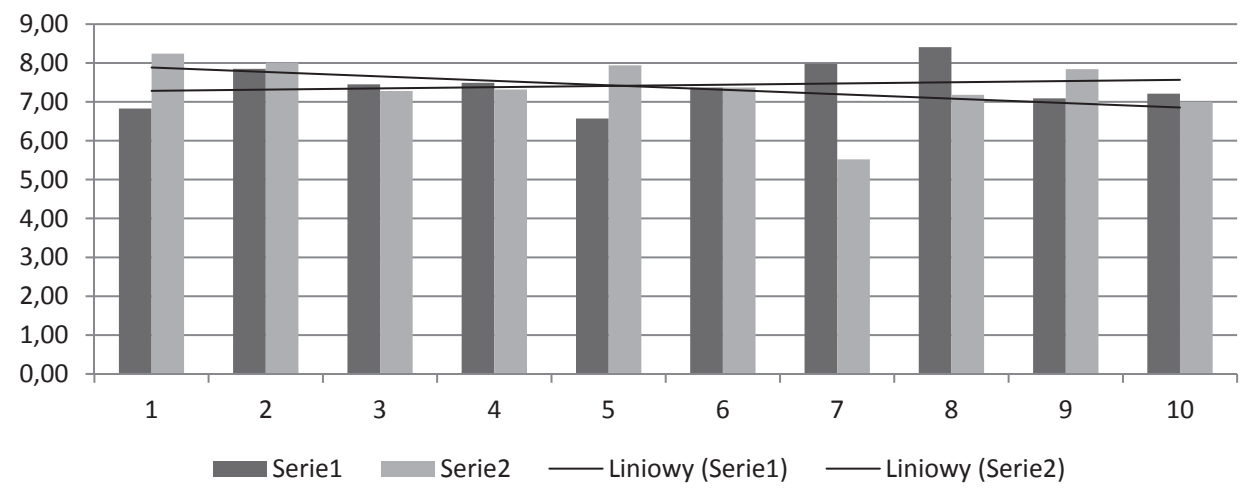

Figure 1: Top 10 World's Most Admired Companies - Social Responsibility versus Top 10 World's Most Admired Companies (2013)

Source: (own setting, based on Fortune \& Hay Group data, 2013, http://money.cnn.com/)

The most important findings, based on the analysis of the two rankings are the following:

- Starbucks (ranked the second on the Social Responsibility dimension and the fifth on the World's Most Admired Companies) and The Walt Disney Company (ranked the eight on the Social Responsibility dimension and the ninth on the World's Most Admired Companies) are the only two companies that are present on both of the Top 10 rankings, while four of the companies from Top Ten - Social Responsibility (Royal Dutch Shell, CH2M Hill, Statoil, and Wyndham Worldwide) are not even present on Top 50 Most Admired Companies;

- Surprisingly, if talking about the average overall scores (which take into account all the nine dimensions of reputations, as they are defined by Fortune \& Hay Group) of the two series, it is higher in the case 
of Top 10 - Social Responsibility (7.425) than in the case of Top 10 Most Admired Companies (7.37), while six out of ten companies present on the Top 10 - Social Responsibility have an higher overall score than the average overall score of Top 10 Most Admired Companies;

- Although, generally speaking, the overall score manifests a decreasing tendency among Top 10 Most Admired Companies (aspect which is rather natural, despite the methodological issues that place, for instance, Southwest Airlines - with a 5.52 overall score, significantly lower than the overall score of each one of the companies in Top 10 - Social Responsibility - on the seventh position among the Most Admired Companies), there is an interesting (opposite) tendency of growing as regards the overall score of Top Ten - Social Responsibility, which may lead to the conclusion that Social Responsibility dimension is rather a weakness than a strength for companies in their search to be among the most admired ones;

- The industries Top 10 - Social Responsibility ranking companies operate in are quite different: two companies (Royal Dutch Shell and Statoil) belong to the Petroleum Refining industry, another two companies (Marriott International and Wyndham Worldwide) belong to Hotels, Casinos, Resorts industry, while one company belongs to each one of the following industries: Food Services (Starbucks), Food and Drug Stores (Whole Foods Market), Engineering, Construction (CH2M Hill), Apparel (Nike), Consumer Food (Nestle) and Entertainment (The Walt Disney Company);

- Even if three of the companies from Top Ten - Social Responsibility (Marriott International, Starbucks, and $\mathrm{CH} 2 \mathrm{M}$ Hill) can also be found among Etisphere Institute 2014 World's Most Ethical Companies (http://ethisphere.com/worlds-most-ethical/wme-honorees/), each one of them was (even recently) involved into (at least one) business ethics or CSR related press scandals: Marriott International (Canellos \& Kleinbard, 2012); Starbucks (Barford and Holt, 2013); CH2M Hill (Weiss, 2011). The same observation is valid for the other seven companies: Whole Foods Market (CBS News, 2012); Royal Dutch Shell (Moshinsky, Doan, \& Brundsen, 2013); Nike (Nisen, 2013); Nestle (Muller, 2013); The Walt Disney Company (Malkin, 2013); Statoil (Gosden, 2013); Wyndham Worldwide (Huffington Post, 2012).

\subsection{Reputation Institute \& Forbes: The World's Most Reputable Companies}

Considering reputation the core of stakeholders support, Reputation Institute and Forbes have released (since 2010) annual rankings of The World's Most Reputable Companies. According to their specific methodology, it "measures the reputation of the 100 most highly regarded companies across 15 countries covering more than $75 \%$ of the global GDP" (http://www.reputationinstitute.com/thought-leadership/global-reptrak-100), starting from a reference base of 2,000 companies, belonging to 25 industries and 40 countries, and by interviewing about 55,000 consumers from 15 different markets.

The 2013 ranking is based on seven key dimensions of corporate reputation: (1.) products/services; (2). innovation; (3). workplace; (4). governance; (5). citizenship; (6). leadership; and (7). financial performance (http://www.reputationinstitute.com/). Table 2 and Figure 2 comparatively illustrate Top 10 rankings for Global CSR Reputation Winners (based on workplace, governance and citizenship dimensions of reputation) and the World's Most Reputable Companies. 
2013 Global CSR Reputation Winners (Top 25)

\begin{tabular}{|c|c|c|c|c|c|c|c|c|}
\hline \multirow{2}{*}{ Rank } & \multirow{2}{*}{ Company } & \multirow{2}{*}{$\begin{array}{l}2012 \\
\text { rank }\end{array}$} & \multirow{2}{*}{ Score } & \multicolumn{5}{|c|}{ The World's Most Reputable Companies (Top 100) } \\
\hline & & & & Rank & Score & Rank & Company & Score \\
\hline 1. & Microsoft & (1) & 72.97 & 7 & 76.23 & 1. & BMW & 78.39 \\
\hline 2. & The Walt Disney Company & (3) & 72.83 & 2 & 77.76 & 2. & The Walt Disney Company & 77.76 \\
\hline 3. & Google & (2) & 72.71 & 4 & 77.15 & 3. & Rolex & 77.23 \\
\hline 4. & BMW & (4) & 72.14 & 1 & 78.39 & 4. & Google & 77.15 \\
\hline 5. & Daimler (Mercedes-Benz) & (6) & 70.65 & 5 & 76.58 & 5. & Daimler (Mercedes-Benz) & 76.58 \\
\hline 6. & Sony & (8) & 69.49 & 6 & 76.30 & 6. & Sony & 76.30 \\
\hline 7. & Intel & $(12)$ & 69.32 & 11 & 74.98 & 7. & Microsoft & 76.23 \\
\hline 8. & Volkswagen & (7) & 69.29 & 13 & 74.38 & 8. & Canon & 76.02 \\
\hline 9. & Apple & (5) & 69.21 & 12 & 74.65 & 9. & Nestle & 75.21 \\
\hline 10. & Nestle & (16) & 69.00 & 9 & 75.21 & 10. & LEGO Group & 75.02 \\
\hline
\end{tabular}

Source: (Reputation Institute \& Forbes, 2013, http://www.rankingthebrands.com/)

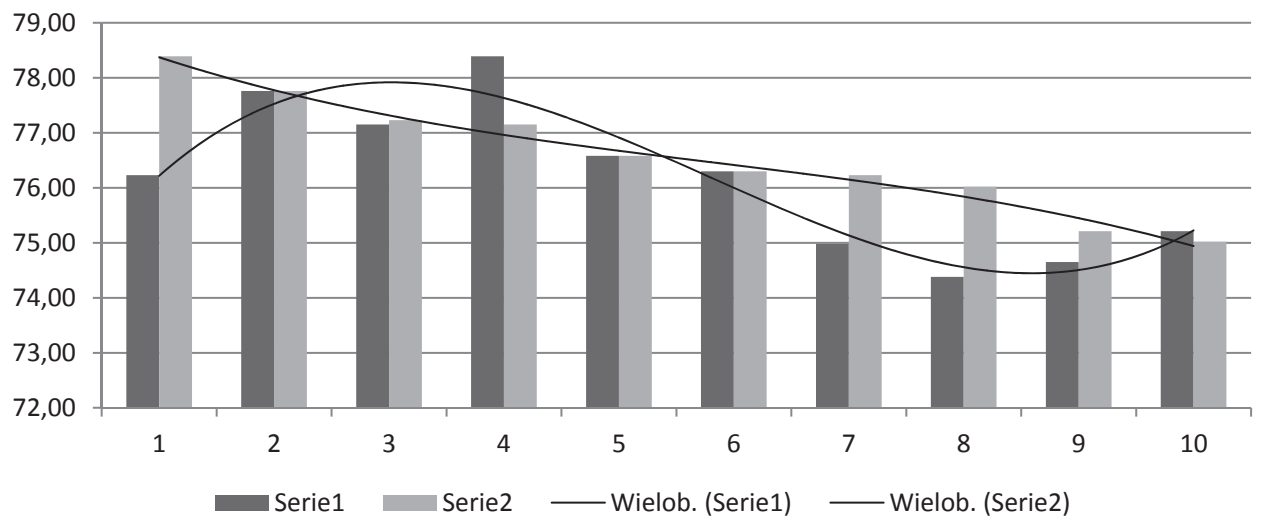

Figure 2: Top 10 Global CSR Reputation Winners versus Top 10 World's Most Reputable Companies (2013) Source: (own setting, based on Reputation Institute \& Forbes data, 2013, http://www.rankingthebrands.com/)

The most important findings, based on the analysis of the two rankings (and considering also the first pair of comparisons referring to World's Most Admired Companies - Social Responsibility and World's Most Admired Companies) are the following:

- The Walt Disney Company (ranking the second on the Global CSR Reputation Winners) and Nestle (ranking the tenth) are the only two companies that are also present on Top 10 - Social Responsibility. As regards the other eight positions, they are occupied by some totally different companies;

- Seven companies out of ten - Microsoft, The Walt Disney Company, Google, BMW, Daimler (Mercedes-Benz), Sony, and Nestle - are present on both Top 10s, which emphasizes a stronger connection between the two series (CSR Reputation Winners and Most Reputable Companies) than in the first case of pairs revealed by Fortune and Hay Group; 
- Considering the global industry criterion for the Top 10 Global CSR Reputation Winners, three companies belong to Computer Industry (Microsoft, Intel and Apple), another three companies belong to Automotive Industry (BMW, Daimler and Volkswagen), two companies operate into the Information and Media industry (The Walt Disney Company and Google), and one company in Food and Manufacturing - all four industries having a pretty high profile in terms of consumers concerns;

- Intel (ranked the seventh) and Nestle (ranked the tenth) are the new entries in 2013 Top 10 Global CSR Reputation Winners in comparison to the previous year, while Colgate-Palmolive and LEGO are the two replaced companies. The other eight companies register only minor variations (or none) regarding their respective ranking;

- Going in depth and considering each one of the basic dimensions of CSR ranking, Google is the most highly rated on workplace, while BMW scores the best on governance and The Walt Disney Company has the highest score on citizenship of all companies;

- As regards the trend line registered by the overall reputation scores of the Top 10 Global CSR Reputation Winners there is no clear tendency, able to connect the two series of scores: CSR and overall reputation.

\subsection{Interbrand: Best Global Brands}

Interbrand, the global landmark in the field of brand value, started its Best Global Brands annual ranking more than 10 years ago (in 2000), emphasizing on brands as "key value creators". Its working methodology envisages: the criteria for company inclusion on one hand, and the "key components of the valuation - analyses of the competitive strength of the brand, the role the brand plays in the purchase decision, and the financial performance of the branded products or services" - on the other hand. (http://www.interbrand.com/ en/best-global-brands/2013/best-global-brands-methodology.aspx).

In 2013, for the third time, Interbrand released also the Best Global Green Brands ranking, report which "examines the gap that exists between a corporation's environmental practices and consumers' perceptions of those practices" - based on a survey involving more than 10,000 consumers from the world's ten largest economies in terms of GDP. So, the positive gap score reflects a higher performance score, while a negative gap score reflects a higher perception score (http://www.interbrand.com/en/best-global-brands/Best-Global-GreenBrands/2013/best-global-green-brands-methodology.aspx). Table 3 and Figure 3 comparatively illustrate Top 10 rankings for Best Global Green Brands and Best Global brands. 
Table 3

2013 Best Global Green Brands

\begin{tabular}{|c|c|c|c|c|c|c|c|c|c|}
\hline \multirow[b]{2}{*}{ Rank } & \multirow[b]{2}{*}{ Company } & \multirow[b]{2}{*}{$\begin{array}{c}\text { Gap } \\
\text { score }\end{array}$} & \multicolumn{7}{|c|}{ Best Global Brands 2013 (Top 100) } \\
\hline & & & Rank & $\begin{array}{l}\text { Vari- } \\
\text { ation }\end{array}$ & $\begin{array}{c}\text { Brand } \\
\text { value } \\
\text { (mill.\$) }\end{array}$ & Rank & Company & $\begin{array}{l}\text { Vari- } \\
\text { ation }\end{array}$ & $\begin{array}{c}\text { Brand } \\
\text { value } \\
\text { (mill.\$) }\end{array}$ \\
\hline 1. & Toyota & -2.53 & 10 & $+17 \%$ & 35,346 & 1. & Apple & $+28 \%$ & 98,316 \\
\hline 2. & Ford & -2.57 & 42 & $+15 \%$ & 9,181 & 2. & Google & $+34 \%$ & 93,291 \\
\hline 3. & Honda & -2.10 & 20 & $+7 \%$ & 18,490 & 3. & Coca Cola & $+2 \%$ & 79,213 \\
\hline 4. & Panasonic & 15.15 & 68 & $+1 \%$ & 5,821 & 4. & IBM & $+4 \%$ & 78,808 \\
\hline 5. & Nissan & 2.06 & 65 & $+25 \%$ & 6,203 & 5. & Microsoft & $+3 \%$ & 58,546 \\
\hline 6. & Johnson \& Johnson & 3.09 & 81 & $+9 \%$ & 4,777 & 6. & GE & $+7 \%$ & 46,947 \\
\hline 7. & Volkswagen & 2.96 & 34 & $+20 \%$ & 11,120 & 7. & Mc Donalds & $+5 \%$ & 41,992 \\
\hline 8. & Danone & -0.62 & 49 & $+6 \%$ & 7,968 & 8. & Samsung & $+20 \%$ & 39,610 \\
\hline 9. & Nokia & 18.5 & 57 & $-65 \%$ & 7,444 & 9. & Intel & $-5 \%$ & 37,257 \\
\hline 10. & Dell & 8.17 & 61 & $-10 \%$ & 6,845 & 10. & Toyota & $+17 \%$ & 35,346 \\
\hline
\end{tabular}

Source: (Interbrand, 2013, http://www.interbrand.com/)

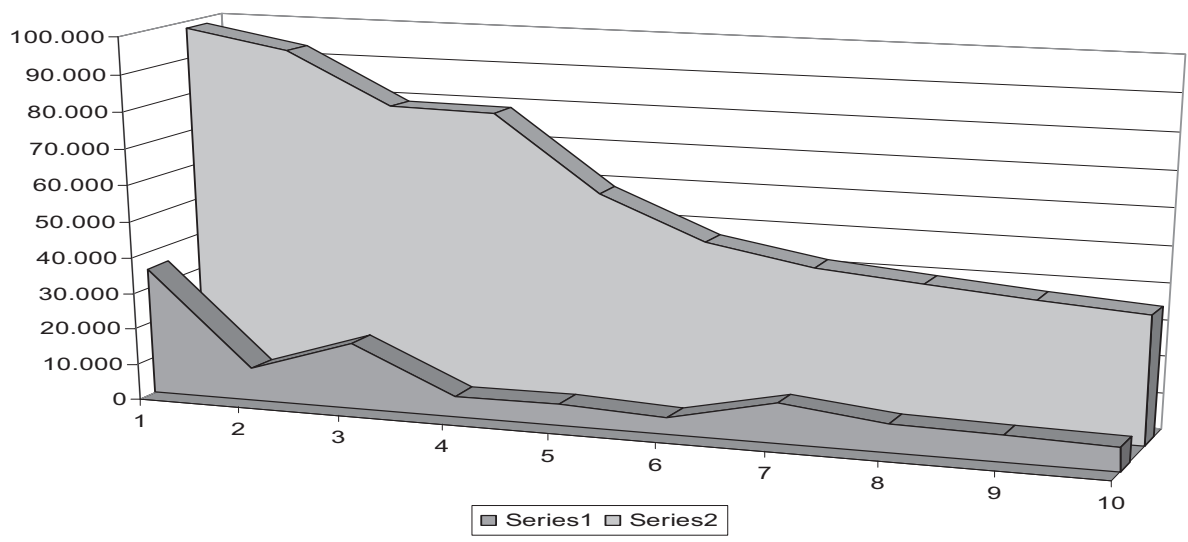

Figure 3: Top 10 Best Global Green Brands versus Top 10 Best Global Brands (2013)

Source: (own setting, based on Interbrand data, 2013, http://www.interbrand.com/)

The most important findings, based on the analysis of the two rankings (and considering also the first two pairs of comparisons referring to World's Most Admired Companies - Social Responsibility and World's Most Admired Companies, on one hand, and to Global CSR Reputation Winners and The World's Most Reputable Companies, on the other hand) are the following:

- Volkswagen (ranked the seventh among the Best Global Green Brands) is the only one company which is also present in Top 10 Global CSR Reputation Winners (on the eight place); no company form the Top 10 Best Global Green Brands is present on the Top 10 - Social Responsibility; 
- There is only one company - Toyota: the winner of the Best Global Green Brands - that can also be found among Top 10 Best Global Brands (but on the last position this time); this could lead to the assumption that the brand value has rather little in common with "the green dimension";

- Six of the Best Global Green Brands (Panasonic, Nissan, Johnson \& Johnson, Volkswagen, Nokia, and Dell) have higher performances and lower perceptions regarding their "green dimension" (and this is especially the case of Panasonic, that registers a 15.15 gap score), while in the case of the other four companies (Toyota, Ford, Honda, and Danone) the situation is the other way around (the brands receive more credit than they actually deserve, but the gaps are significantly lower);

- The variation from one year to another - in terms of brand value - is very diverse; the extreme values for Top 10 Best Global Green Brands are represented by Nokia (- 65\% variation) and Nissan (+ 25\% variation), while in the case of Top 10 Best Global Brands the variation gap is not so significant: Intel (- $5 \%$ variation) and Google (+ 34\% variation);

- The Top 3 Best Global Green Brands (Toyota, Ford and Honda) operate in the automotive industry, as well as another two of the Top 10 leading companies (Nissan and Volkswagen). The other represented industries (each one of them counting only one company) are the following: electrical \& electronics (Panasonic); consumer products (Johnson \& Johnson); food-manufacturing (Danone); telecommunications (Nokia); and computer (Dell);

- The differences between the two data series (in terms of brand value) are the most visible ones, if considering Toyota - the Best Global Green Brand - which is valuating almost double (\$ 35,346 mill) in comparison with Honda (\$18,490 mill) - ranked the third on the same criterion, with the highest brand value after Toyota. More than that, seven companies out of the Top 10 Best Global Green Brands have a brand value under \$ 1,000 mill, while Apple alone (The Best Global Brand of 2013) has a brand value of \$ 98,316 mill.

\subsection{Reflections on the business case for CSR}

As regards the business case for CSR, the opinions expressed by the authors of the three pairs of rankings vary quite a lot.

Based on the 2013 Global CSR Reputation Winners Report, Reputation Institute argues that "CSR drives support (...) but the return on investment is low from CSR". This conclusion comes out from the consumers' feedback regarding the three dimensions of CSR (citizenship, governance and workplace): 56-61\% of consumers results to be "neutral or not sure if companies can be trusted to deliver" on the three dimensions, despite the fact that the average spending on CSR related activities of the companies from Top 100 is about $\$ 50$ mill a year (Reputation Institute, 2013).

On the other hand, considering its 15 years of tradition in working with Fortune and developing the World's Most Admired Companies ranking, Hay Group insists on the direct impact of CSR on business performance, especially if taking into account the strategic, long-time perspective of business; in this light, it emphasizes on the "direct financial consequences" of being one of "the most admired", and, more than that, on the fact that "these benefits endure over time" (Hay Group, 2012). So, building reputation takes time, but it is paying, and it is paying more over time.

Interbrand, at its turn, in order to develop its Best Global Brands ranking, offers a specific valuation methodology that "brings together market, brand, competitor, and financial data into a single framework within which a brand's performance can be assessed, a roadmap for improvement identified, and the financial impact of investing in (...) brand quantified" (http://www.interbrand.com/). When talking about Best Global Green Brands, "it's all about striking a balance between performance and perception, and being transparent, open, and honest about the journey (with its occasional stumbles) on the road to sustainability" (Frampton, 2013). 
Considering all the aforementioned findings and reflections, it become obvious that "CSR is increasingly crucial to both business and societal success", in terms of means - reflected in the way products/services are delivered - and ends - expressed through the legitimacy of companies (Werther, \& Chandler 2011, p. xxii). Given this context, Visser (2014) has identified "the four DNA elements of CSR 2.0" - that have to be integrated within the business models operating into the systemic stage of CSR, which is dominated by the responsibility paradigm: "value creation; good governance; societal contribution; and environmental integrity" (Visser, 2014). This kind of approach is consonant with Porter and Kramer's (2011) "principle of shared value, which involves creating economic value in a way that also creates value for society by addressing its needs and challenges" (Porter and Kramer, 2011). The internalization and practice of shared value at the company's level will eventually be able to deliver, as Rothaermel (2013) has suggested, a "reconciliation" between the perspective of shareholder value creation and CSR.

\section{CONCLUSIONS}

The analysis has offered some very interesting insights as concerns each one of the ranking pairs, but - due to the methodological differences behind the three different rankings (not to mention their slightly different aims) - it was not very conclusive when comparing the different rankings pairs between them: there are only three companies that are present in two Top 10 - The Walt Disney Company (ranked the second on the Global CSR Reputations Winners and the eight on the World's Most Admired Companies - Social responsibility); Nestle (ranked the tenth on the Global CSR Reputations Winners and the seventh on the World's Most Admired Companies - Social responsibility); and Volkswagen (ranked the eight on the Global CSR Reputations Winners and the seventh on the Best Global Green Brands) - and no company present on the three of them.

Although all of the global winners explicitly recognize that CSR represents an important issue for them and they are spending accordingly on it, the pay back does not always seem to be as expected. The reason behind this situation may rely, once again, on perception - coming especially from lack of trust; and all the CSR and/or business ethics related press scandals that surround and target some of these companies on pretty regular basis are nothing than arguments in favor of this feeling. This vicious circle may be broken only if and when the companies will understand the strategic value of CSR and will start to genuinely operate based on the principles of shared value - and they will be perceived as to do so. Therefore, it will be very interesting for future researches to keep an eye on the dynamics of both the behaviors towards CSR of the global winners of today and their perceived strategic value - through the lens of the stakeholders.

\section{REFERENCES}

Bansal, P. (2002) The corporate challenges of sustainable development, The Academy of Management Executive, 16(2), p. $122-131$.

Barford, V., \& Holt, G. (2013) Google, Amazon, Starbucks: The rise of "tax shaming", BBC News magazine, May 21, http://www.bbc.com/news/magazine-20560359.

Bercerra, M. (2009) Theory of the Firm for Strategic management. Economic Value Analysis. Cambridge University Press.

Bhattacharya, C. B., Sen, S., \& Korschun, D. (2011) Leveraging corporate responsibility: The stakeholder route to maximizing business and social value. Cambridge University Press.

Blowfield, M., Murray, A. (2011) Corporate Responsibility, Oxford University Press.

Canellos, P., \& Kleinbard, E. (2012) Did Romney enable a company's abusive tax shelter?, CNN, August 9, http://edition.cnn.com/2012/08/08/opinion/canellos-kleinbard-romney-taxes/. 
Carroll, A. B. (1999) Corporate social responsibility evolution of a definitional construct, Business \& society, 38(3), p. 268-295.

Carroll, A. B., \& Shabana, K. M. (2010) The business case for corporate social responsibility: a review of concepts, research and practice, International Journal of Management Reviews, 12(1), p. 85-105.

CBS News (2012) US peanut butter recall expands to more stores including Whole Foods, Target, October 2, http:// www.cbsnews.com/news/us-peanut-butter-recall-expands-to-more-stores-including-whole-foods-target/.

Crane, A., Matten, D., \& Spence, L. J. (2008) Corporate social responsibility: in global context, Corporate Social Responsibility: Readings and Cases in Global Context, p. 3-20.

Elkington, J. (1999) Cannibals with forks. Oxford: Capstone.

Ethisphere Institute (2014) 2014 World's Most Ethical Companies, http://ethisphere.com/worlds-most-ethical/wmehonorees/.

Fassin, Y. (2009). The stakeholder model refined. Journal of Business Ethics, 84(1), 113-135.

Fortune (2013) World's Most Admired Companies. Available at http://money.cnn.com/gallery/news/companies/2013/02/28/most-admired-top-companies.fortune.

Frampton, J. (2013) The Sustainable Opportunity, http://www.interbrand.com/en/best-global-brands/Best-GlobalGreen-Brands/2013/the-sustainable-opportunity.aspx.

Freeman, R. E. (2010) Strategic management: A stakeholder approach. Cambridge University Press.

Friedman, A. L., \& Miles, S. (2006) Stakeholders: Theory and Practice: Theory and Practice. Oxford University Press.

Friedman, A. L., \& Miles, S. (2002) Developing stakeholder theory, Journal of management Studies, 39(1), p. 1-21.

Gholami, S. (2011) Value Creation Model through Corporate Social Responsibility (CSR), International Journal of Business \& Management, 6(9).

Gosden, E. (2013) BP, Shell and Statoil investigated over suspected oil price manipulation, The Telegraph, May 14, http:// www.telegraph.co.uk/finance/newsbysector/energy/10057017/BP-Shell-and-Statoil-investigated-over-suspectedoil-price-manipulation.html.

Gupta, A.K., Westney, D.E. (2003) Smart Globalization: Designing Global Strategies, Creating Global networks, MIT Sloan. Management Review.

Hahn, R. (2011) Integrating corporate responsibility and sustainable development: A normative-conceptual approach to holistic management thinking, Journal of Global Responsibility, 2(1), p. 8-22.

Hay Group (2013) Who are Fortune World's Most Admired Companies 2013. Available at http://www.haygroup.com/ in/best_companies/index.aspx?id=11640.

Hay Group (2012) Lighting the path to success, http://www.haygroup.com/fortune/downloads/2012-FORTUNELighting-the-path-to-success.pdf.

Hopwood, B., Mellor, M., \& O’Brien, G. (2005) Sustainable development: mapping different approaches, Sustainable development, 13(1), p. 38-52.

Huffington Post (2012) Wyndham Worldwide Corp. Sued Over Credit Card Breaches, June 26, http://www.huffingtonpost.com/2012/06/26/wyndham-credit-card-breach_n_1628005.html.

Interbrand (2013) Best Global Brands 2013. Available at http://www.interbrand.com/en/best-global-brands/2013/BestGlobal-Brands-2013.

Jo, H., \& Harjoto, M. A. (2011), Corporate governance and firm value: The impact of corporate social responsibility, Journal of Business Ethics, 103(3), 351-383.

Kolk, A., \& Van Tulder, R. (2010) International business, corporate social responsibility and sustainable development, International Business Review, 19(2), p. 119-125.

Kotler, P., Lee, N. (2005) Corporate Social Responsibility. Doing the Most Good for Your Company and Your Cause, John Wiley \& Sons, Inc.

Lin, L. W. (2010) Corporate Social Responsibility in China: Window Dressing or Structural Change, Berkeley J. Int'l L., 28 , 64. 
Malkin, B. (2013) Disneyworld and Disneyland change rules on disabled access after abuse scandal, The Telegraph, September 24, http://www.telegraph.co.uk/news/worldnews/northamerica/usa/10329792/Disneyworld-and-Disneyland-change-rules-on-disabled-access-after-abuse-scandal.html.

Matten, D., \& Moon, J. (2008) "Implicit" and "explicit" CSR: A conceptual framework for a comparative understanding of corporate social responsibility, Academy of Management Review, 33(2), p. 404-424.

McWilliams, A., \& Siegel, D. S. (2011) Creating and Capturing Value Strategic Corporate Social Responsibility, Resource-Based Theory, and Sustainable Competitive Advantage, Journal of Management, 37(5), p. 1480-1495.

Morand, M., \& Rayman-Bacchus, L. (2006) Think global, act local: Corporate Social Responsibility Management in Multinational Companies, Social Responsibility Journal, 2(3/4), p. 261-272.

Moshinsky, B., Doan, L., \& Brundsen, J. (2013) Enron no lesson to traders as EU probes oil-price manipulation, Bloomberg News, May 21, http://business.financialpost.com/2013/05/21/enron-no-lesson-to-traders-as-eu-probesoil-price-manipulation/?_lsa $=2 \mathrm{f} 56$-ee2f.

Mukherjee, A. (2013) From CSR to MCSR: the journey towards mandatory corporate social responsibility in India, Golden Research Thoughts, 3(2).

Muller, M. (2013) Nestle baby milk scandal has grown up but not gone away, The Guardian, February 13, http://www. theguardian.com/sustainable-business/nestle-baby-milk-scandal-food-industry-standards.

Nisen, M. (2013) How Nike Solved Its Sweatshop Problem, Business Insider, May 9, http://www.businessinsider.com/ how-nike-solved-its-sweatshop-problem-2013-5.

Orlitzky, M., Siegel, D. S., \& Waldman, D. A. (2011) Strategic corporate social responsibility and environmental sustainability, Business \& Society, 50(1), p. 6-27.

Peloza, J., \& Shang, J. (2011) How can corporate social responsibility activities create value for stakeholders? A systematic review, Journal of the Academy of Marketing Science, 39(1), p. 117-135.

Porter, M. E., \& Kramer, M. R. (2006) The link between competitive advantage and corporate social responsibility, Harvard business review, 84(12), p. 78-92.

Porter, M.E., \& Kramer, M.R. (2011) Creating Shared Value, Harvard Business Review, January

Rahim, M. M. (2013), Legal Regulation of CSR in Weak Economies: The Case of Bangladesh, Legal Regulation of Corporate Social Responsibility (p. 179-273), Springer Berlin Heidelberg.

Reputation Institute (2013) 2013 The World's Most Reputable Companies. Available at http://www.reputationinstitute. com/thought-leadership/global-reptrak-100.

Rothaermel, F. T. (2013) Strategic Management: Concepts. McGraw-Hill Irwin.

Salzmann, O., Ionescu-Somers, A., \& Steger, U. (2005) The business case for corporate sustainability: literature review and research options, European Management Journal, 23(1), p. 27-36.

Servaes, H., \& Tamayo, A. (2013) The impact of corporate social responsibility on firm value: The role of customer awareness, Management Science, 59(5), p. 1045-1061.

Smith, J. (2013) The World's Most Reputable Companies, Forbes, 04.09.2013. Available at http://www.forbes.com/sites/ jacquelynsmith/2013/04/09/the-worlds-most-reputable-companies-2/.

Visser, W. (2011) CSR 2.0: from the age of greed to the age of responsibility, Critical Studies on Corporate Responsibility, Governance and Sustainability, 1, p. 231-251.

Weiss, R. (2011) The Case of CH2M Hill: \$2 Billion in Crony Stimulation, Accuracy in Media, November 30, http:// www.aim.org/special-report/the-case-of-ch2m-hill-2-billion-in-crony-stimulation/.

Werther Jr, W. B., \& Chandler, D. (2011) Strategic corporate social responsibility: Stakeholders in a global environment. Los Angeles: Sage. 